\title{
Elucidation of Genotype $\times$ Environment Interaction for Identification of Stable Genotypes to Grain Yield of Rice (Oryza sativa L.) Varieties in Bangladesh Rainfed Condition
}

\author{
S K Debsharma ${ }^{1 *}$, P R Roy², R A Begum², K M Iftekharuddaula ${ }^{1}$
}

\begin{abstract}
The research was evaluated in seven ecological zones throughout the country following randomized complete block design with three replications in each location. The combined analysis of variance for grain yield indicated that the differences among all sources of variation were highly significant $(\mathrm{P}<0.01)$. Environment $(\mathrm{E})$, Genotype $(\mathrm{G})$ and $\mathrm{G} \times \mathrm{E}$ interaction effects explained by $25.54 \%, 17.02 \%$ and $48.97 \%$ for inbred and $35.26 \%, 17.03 \%, 31.23 \%$ for hybrid of the total sum of square, respectively. Locations E2 (Chattogram); E3 (Dhaka) for inbred and E2 (Chattogram); E4 (Khulna); E5 (Rajshahi); E7 (Sylhet) for hybrid varieties were found most discriminating and more informative among all. Ideal environment was found in E6 (Rangpur) for inbred and E4 (Khulna) for hybrid varieties. According to GGE mean and stability biplot, the most stable genotypes were G18 (BRRI dhan34); G26 (BRRI dhan52); G28 (BRRI dhan57); G19 (BRRI dhan37); G13 (BR25); G27 (BRRI dhan56); G21 (BRRI dhan39) for inbred and G2 (BADC hybrid dhan-2); G4 (BADC hybrid dhan-6); G5 (Bayer hybrid dhan-4) for hybrid compared to the other genotypes. The ideal genotypes were found G18 (BRRI dhan34) for inbred and G26 (BRRI hybrid dhan6) for hybrid varieties. In summary, we identified stable genotypes adapted across the environments for grain yield. These genotypes can be used as commercial cultivation with sustainable production as well as a parent/pre-breeding material in future rice breeding program.
\end{abstract}

Key words: Genotype, environment, rice, yield, rainfed.

\section{INTRODUCTION}

Rice is an important cereal crop which received the most attention of specialists in plant breeding and production technologies. However, its production is limited by the adverse environmental conditions (Wassmann et al., 2009). Multi-environment yield trials are conducted for different crops throughout the world (Yan and Rajcan, 2002; Dehghani et al., 2006) not only to identify high yielding cultivars but also to identify sites that best represent the target environment (Yan, 1999; Yan et al., 2000; Yan and Hunt, 2001). It is often important to the plant breeders for developing improved genotypes and reduces the genetic progress in plant breeding program through minimizing the association between phenotype and genotype (Comstock and Moll, 1963). Even for similar ecological conditions, general adaptability is an important quality in a variety. According to Sharma (1994), adaptability refers to the capacity of a genotype to macroenvironmental factors in its favour in order to a consistent performance over time and locations. Development of location specific variety has been considered for future challenge and sustainable food production (Iftekharuddaula et al., 2002). Performance of a genotype in diverse environments is a true evaluation of its inherent potential adaptiveness (Pandey et al., 1981).

Thus, ideal trial site and genotype identification are needed through effective statistical tools. For instance, regression coefficient (Finlay and Wilkinson, 1963), sum of squared deviations from regression (Eberhart and Russel, 1966), stability variance (Shukla, 1972), coefficient of determination (Pinthus, 1973), coefficient of variability

1Plant Breeding Division, Bangladesh Rice Research Institute, Gazipur-1701, Bangladesh, 2Seed Certification Agency (SCA), Ministry of Agriculture, Government of the People's Republic of Bangladesh.

*Corresponding author's E-mail: sanjoybrri@gmail.com 
(Francis and Kanneberg, 1978) and additive main effects and multiplicative interaction (AMMI) (Gauch and Zobel, 1988; Annicchiarico, 1997). However, Yan (1999) and Yan et al., (2000) proposed another methodology known as a Genotype and Genotype by Environment (GGE) biplot for graphical display of Genotype by Environment Interaction (GEI) pattern of multi-location data with many advantages. In biplot study, both genotype $(G)$ main effects and genotype $\times$ environment interaction $(\mathrm{G} \times \mathrm{E})$ are considered simultaneously for genotype and environment evaluation (Yan and Kang, 2002). Through data visualization, a "which-won-where" view of biplot helps to mark distinct megaenvironments to identify the best performing genotypes in the respective environments (Gauch and Zobel, 1997; Yan and Hunt, 1998; Yan, 1999; Yan et al., 2000). Moreover, GGE and AMMI models are widely useful for detection of $G \times E$ interaction by visualizing the graphical representation. Also, ranking of environments and genotypes means stability and comparing the genotype with the popular cultivar is essential for location specific variety development and the biplot analysis paved the way to more reliable and proper interpretation in multi-location trials.
Thus, the present study was undertaken to evaluate the yield performance of each genotype, examine the possible existence of different mega environments, identify the winning genotype for each mega environment and point out the best location as a representative rainfed conditions as well as select stable and superior genotypes for commercial cultivation in Bangladesh.

\section{MATERIALS AND METHODS}

\section{Plant materials and testing locations}

A total of 48 rice genotypes, 36 inbred and 12 hybrid rice genotypes were evaluated, consisted of 28 Bangladesh Rice Research Institute (BRRI), 8 Bangladesh Institute of Nuclear Agriculture (BINA), 2 Bangabandhu Sheikh Mujibur Rahman Agricultural University (BSMRAU), 3 Bangladesh Agricultural Development Corporation (BADC), 2 Bayer Crop Science Private Company (BCS), 3 Supreme Seed Company Limited (SSC), 1 Building Resources Across Communities (BRAC), 1 Petrochem Agro Industries Limited (PAIL) (Table 1). Table 2 shows the environmental codes of different location based trials with these varieties.

Table 1. A list of rainfed lowland rice genotypes developed by different research institutes in Bangladesh.

\begin{tabular}{lccccc}
\hline Variety & Genotype & Place of collection & Variety & Genotype & Place of collection \\
\hline Inbred & & & & Inbred & \\
\hline BR10 & G1 & BRRI & BRRI dhan75 & G26 & BRRI \\
BR11 & G2 & BRRI & Binasail & G27 & BINA \\
BR22 & G3 & BRRI & Binadhan-4 & G28 & BINA \\
BR23 & G4 & BRRI & Binadhan-7 & G29 & BINA \\
BR25 & G5 & BRRI & Binadhan-11 & G30 & BINA \\
BRRI dhan30 & G6 & BRRI & Binadhan-12 & G31 & BINA \\
BRRI dhan31 & G7 & BRRI & Binadhan-15 & G32 & BINA \\
BRRI dhan32 & G8 & BRRI & Binadhan-16 & G33 & BINA \\
\hline
\end{tabular}


Table 1. Continued.

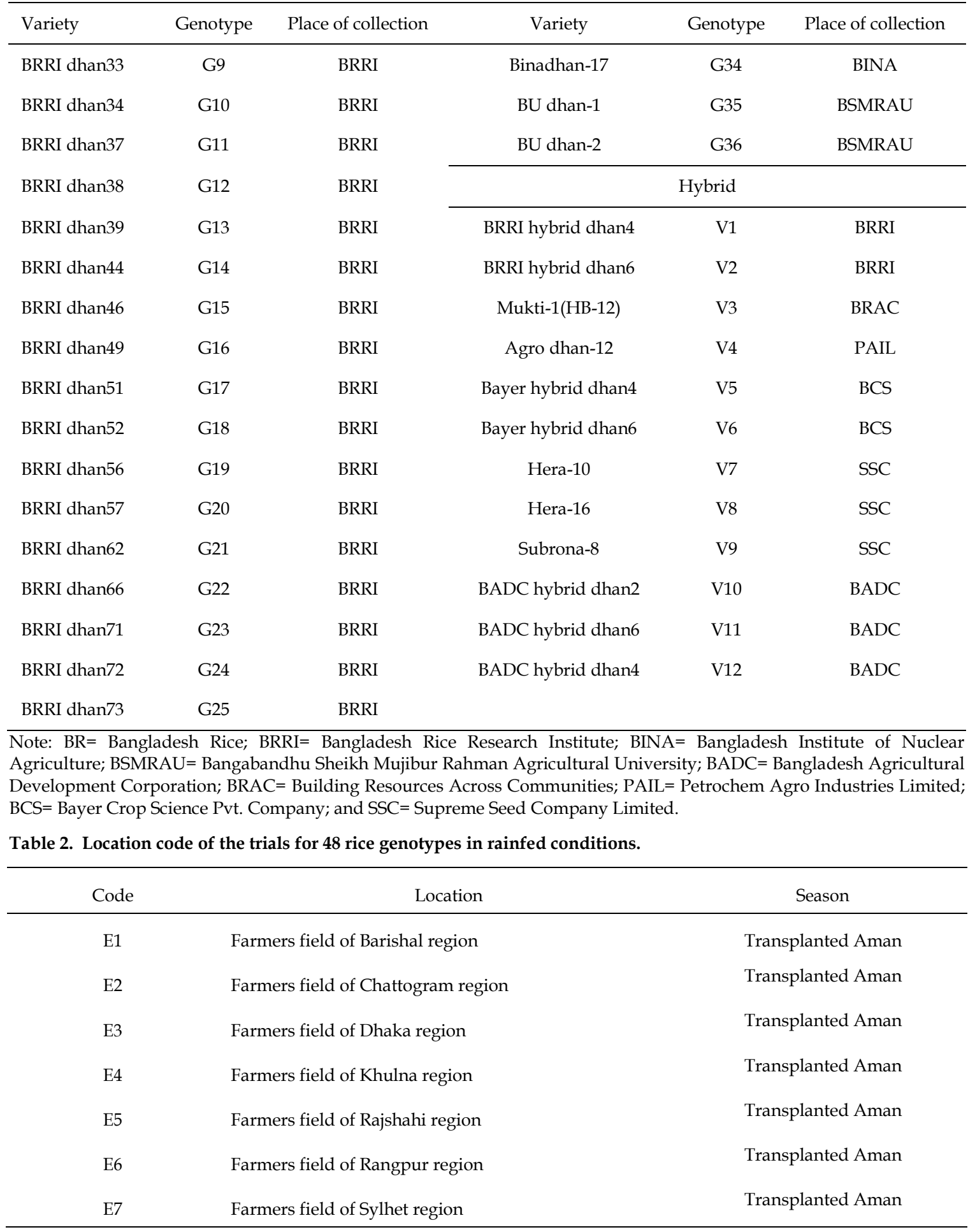




\section{Field experiment and experimental design}

The experiment was conducted in rainfed ecosystem in the 2018. Seeding was established at various study locations from mid to last week of July, and transplanting was completed within third to fourth week of August in the year of 2018. Thirty to 35 day-old seedlings were transplanted at a spacing of $20 \times 15 \mathrm{~cm}$ with $2-3$ seedlings per hill. The unit plot size was $5.4 \mathrm{~m} \times 2.4 \mathrm{~m}$. The field layout was randomized complete block design with three replications. Fertilizers were applied @ 234:87:115:78:12 kg Urea, TSP, MoP, Gypsum, Zinc sulphate per hectare respectively. All fertilizers except urea were used as basal during final land preparation. Urea was applied in three splits at 10-15 days after transplanting, 4-5 tillering stage and 5-7 days before panicle initiation stage. Crop management such as weeding, irrigation etc was done in time. Insects, diseases and other pests were controlled properly. The harvested area was $10.2 \mathrm{~m}^{2}$. Two border rows were transplanted to minimize the border effects. The grain yield (tha ${ }^{-1}$ ) data were collected at $14 \%$ moisture level. Data were collected followed by standard method as described by Yoshida et al., (1976). The yield $\left(\right.$ tha $\left.^{-1}\right)$ conversion formula as follows:
Yield $\left(\right.$ tha $\left.^{-1}\right)=$

$$
100-\text { Grains moisture content (\%) }
$$

\section{Plot yield}

\section{$100-14$}

\section{Statistical Analysis}

The grain yield data for 48 genotypes in seven environments were used to perform combined analysis of variance (ANOVA) to determine the effects of environment $(\mathrm{E})$, genotype $(\mathrm{G})$ and their interactions. Combined analysis of variance, co-efficient of variation was measured by STAR software (version 2.0.1, http://bbi.irri.org) and broad sense heritability $\left(\mathrm{h}^{2}\right)$ for each trial was generated by PB Tools software (version 1.3). GGE biplot was constructed through principal component analysis performed by PB Tools software (version 1.3, http://bbi.irri.org) with the model equation:

$\mathrm{Y}_{\mathrm{ij}}-\mu+\mathrm{G}_{\mathrm{i}}+\mathrm{E}_{\mathrm{j}}+\Sigma \lambda_{\mathrm{k}} \mathrm{a}_{\mathrm{ik}} \gamma_{j \mathrm{j}}+\mathrm{e}_{\mathrm{ij}}$

Where $Y_{i j}$ is the yield of $i^{\text {th }}$ genotype in the $j^{\text {th }}$ environment; $G_{i}$ and $E_{j}$ represent the genotype and environment deviations from the grand mean, respectively; $\mu$ denotes the grand mean $\lambda_{k}$ is the eigenvalue of the PCA axis $k$; $a_{i k}$ and $\gamma_{j k}$ indicate the genotype and environment PC scores, respectively, for the axis $\mathrm{k}$ and $\mathrm{e}_{\mathrm{ij}}$ denotes the error term.

\section{RESULTS AND DISCUSSION}

\section{Combined analysis of variance}

Analysis of variance was done for the grain yield by 36 inbred and 12 hybrid rice varieties experimented in T. Aman 2018 (Table 3). The combined analysis revealed that the yield of rice genotypes was highly significant $(\mathrm{P}<0.01)$ influenced and contributed the major part by environment (E), which explained $37.88 \%$ and $35.26 \%$ of the total variation for inbred and hybrid varieties, respectively. Additionally, the relative contribution of genotype sum of squares was found $17.02 \%$ and $17.03 \%$ for inbred and hybrid respectively. Genotype by Environment $(G \times E)$ contributed the most $48.97 \%$ to the total variation for inbred varieties followed by $31.23 \%$ for hybrid varieties. Greater portion of total variation was explained by genotype $\times$ environment interaction effect in inbred where environment in hybrid indicating that the environments were diverse and a major part of variation in grain yield was reflected from environmental changes (Table 3). The highly significant genotype $\times$ environment interaction effects for 
grain yield confirmed that genotypes may be selected for adaptation to specific environments. This finding was found in Aina et al., (2009) in cassava, Fentie et al., (2013) in finger millet; $\mathrm{Xu}$ et al., (2014), Akter et al., (2015) and Debsharma et al., (2020) in rice. The presence of a significant proportion of GEI is necessary for stability analysis of rice. This is in harmony with the findings of Samyuktha et al., (2020) in mungbean.

\section{Grouping of test environments relation to ideal environments}

Multi-environment trials are being conducted by plant breeders around the respective trial sites to evaluate superior genotypes with wider adaptability. To visualize the relationship between environments, lines are drawn to connect the test environments to the biplot origin known as environment vectors. The most discriminating environment is a virtual environment that has the longest vector of all test environments (Yan and Hunt, 2001). For inbred varieties, The GGE biplot was explained $41.5 \%$ for PC1, $26.9 \%$ for PC2 and $68.4 \%$ of the total variation or interaction of the environments. Two distinct clusters were observed in the inbred GGE biplot study (Yan and Tinker, 2006). One contains E1 (Barishal), E2 (Chattogram), E4 (Khulna) and E7 (Sylhet)); the other cluster contains E3 (Dhaka), E5
(Rajshahi) and E6 (Rangpur). Among seven environments, E1 (Barishal), E4 (Khulna) and E7 (Sylhet) were closely associated which belonged to first cluster (Fig.1a ). The location E2 (Chattogram) showed negative or no correlation with E3 (Dhaka) and E5 (Rajshahi) indicates moderately large $\mathrm{G} \times \mathrm{E}$ interaction due to presence of wide obtuse $\left(<90^{\circ}\right)$ angle. Also, location E3 (Dhaka) found negative or no correlation with E1 (Barishal), E4 (Khulna) and E7 (Sylhet). E2 (Chattogram) and E3 (Dhaka) had the longest vector and making it more discriminating (informative) than other the environments. E6 (Rangpur) have very short vector and considered as an ideal environment for testing genotypes for inbred varieties with its representativeness and appreciable discriminating ability.

For hybrid varieties (Fig. 1b), GGE biplot was accounted $44 \%$ for PC1, $21.7 \%$ for PC2 and $65.7 \%$ of the total variation of the environments. There were two cluster of environments, one containing E3 (Dhaka) and E6 (Rangpur); second cluster containing E4 (Khulna) and E5 (Rajshahi). Among these two, E3 and E6 were closely related (Fig. 1b). E2 (Chattogram), E4 (Khulna), E5 (Rajshahi) and E7 (Sylhet) had the longest vector and indicates highly discriminating. There are negative or no correlation between E1

Table 3. Analysis of variance of rice grain yield ( $t$ ha$\left.^{-1}\right)$ across seven environments for rainfed condition in Bangladesh.

\begin{tabular}{lcccccc}
\hline \multirow{2}{*}{ Source of variation } & \multicolumn{3}{c}{ Inbred } & \multicolumn{3}{c}{ Hybrid } \\
\cline { 2 - 7 } & DF & Mean square & Explained SS (\%) & DF & Mean square & Explained SS (\%) \\
\hline Env & 6 & $37.88^{* *}$ & 25.54 & 6 & $15.03^{* *}$ & 35.26 \\
Rep within Env & 14 & 0.08 & 0.12 & 14 & 0.20 & 1.12 \\
Genotype & 35 & $4.32^{* *}$ & 17.02 & 11 & $3.96^{* *}$ & 17.03 \\
Env : Genotype & 210 & $2.07^{* *}$ & 48.97 & 66 & $1.20^{* *}$ & 31.23 \\
Pooled Error & 490 & 0.15 & 8.34 & 154 & 0.25 & 15.35 \\
Total & 755 & & & 251 & & \\
\hline
\end{tabular}

Note: DF= Degree of freedom; Env= Environment; Rep within Env= Replication with environment; SS= Sum of square. **indicate significant at $\mathrm{P}<0.01$ probability level. 


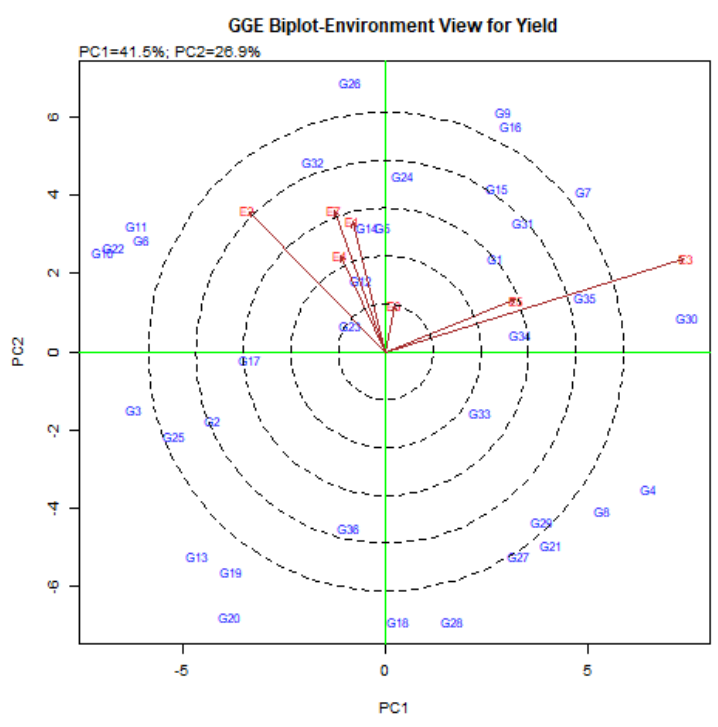

(a) Inbred

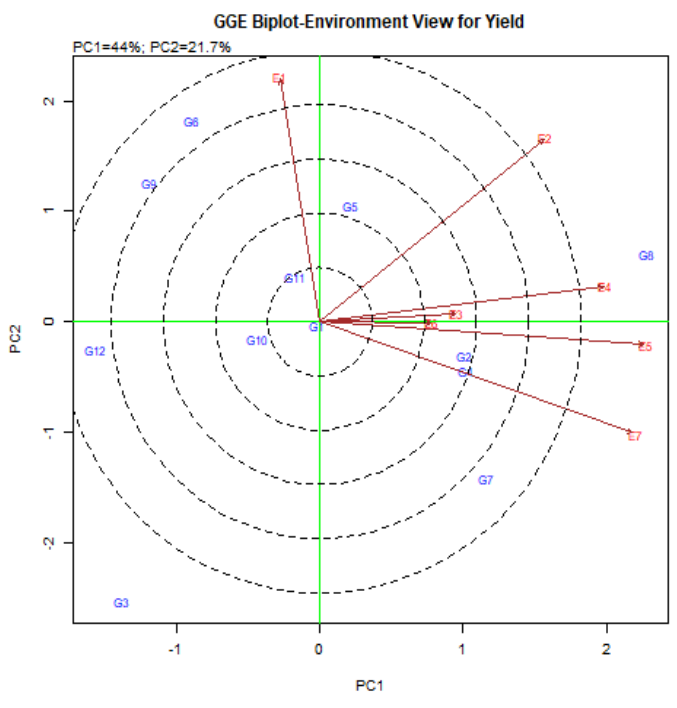

(b) Hybrid

Fig. 1. Association among the test environments of rice genotypes evaluated across seven environments of Bangladesh for grain yield.

(Barishal) and E7 (Sylhet) due to its largest angle (more than $90^{\circ}$ ). The location E6 (Rangpur) and E3 (Dhaka) were highly representative (Fig. 1b). Yan and Kang (2003) described that the degree and causes of $\mathrm{G} \times \mathrm{E}$ interaction is useful for identifying ideal test locations and best performing genotypes from multi environment trials. As Kaya et al., (2006) reported, the presence of close associations between testing environments reveals that similar information about the genotypes could be obtained from fewer test environments and hence there could be better potential to reduce testing cost under limited resources.

\section{Identification of ideal environment}

Discriminating power and representativeness of the GGE biplot is an important measure of testing environment (Dehghani et al., 2006). The length of concentric circles on the biplot helps to visualize the length of the environment vectors which is proportional to standard deviation within the respective environments on the biplot and also shows the discriminating ability of the environments (Yan and Tinker, 2006). Average Environment Axis (AEA) is the line that passes through the average environment (represented by small circle) and biplot origin. The cosine of the angle between the two environments is used to approximate the relation between them (Yan and Tinker, 2006).

In the inbred varieties, E6 (Rangpur) had the narrowest angle with average environment axis (AEA) (Fig. 2a). Thus, it was highly representative among all the locations followed by E1 (Barishal) and E5 (Rajshahi). In opposite, E2 (Chattogram) and E3 (Dhaka) showed the least discriminating ability and were the least representative locations. Considering the above mentioned criteria, E6 (Rangpur) was the ideal location for testing inbred varieties. For the hybrid varieties, E4 (Khulna) showed a smaller angle with the AEA and thus was a highly representative environment followed by E3 (Dhaka) and E6 (Rangpur) (Fig. 2b). Considering the ideal environment criteria, 
the location E4 (Khulna) can be considered ideal environment for evaluating hybrid varieties throughout the country. Yan and Tinker (2006) explained that the narrower angle of two arrows means the closer relation between two environments. The wider angle of two arrows means the more variation of results, because of the bigger effect of $G \times E$ of the observed traits.

\section{Mean grain yield and its stability of inbred and hybrid genotypes}

Visualization of GGE biplot is very useful to evaluate and find the most stable genotypes (Farshadfar et al., 2013). Genotypes laid in the concentric area were more stable in giving the yield compared to the genotypes laid outside, even though the environmental effect was very strong. Within mega-environment, genotypes should be evaluated on both mean performance and stability across environments. Figs. $3 \mathrm{a}$ and $3 \mathrm{~b}$ show averageenvironment coordination (AEC) views of the GGE biplot for grain yield. Table $4 \mathrm{a}$ and $4 \mathrm{~b}$ shows the yield performances and genotypes with code.

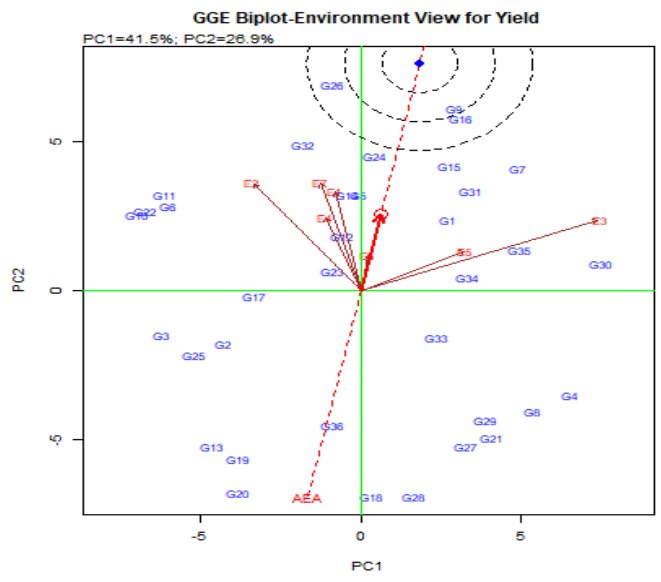

(a) Inbred
For inbred varieties, on the basis of GGE biplot G18 (BRRI dhan34) is the ideal genotype (shown by the bold dot in the center of the concentric area) (Fig. 3a) (Table $5)$. There were seven genotypes laid in the concentric area, i.e. G18 (BRRI dhan34), G26 (BRRI dhan52), G28 (BRRI dhan57), G19 (BRRI dhan37), G13 (BR25), G27 (BRRI dhan56) and G21 (BRRI dhan39) were the most stable genotypes, indicated by their positions which were closely on the AEA lines having very small vector deviation. It meant that these genotypes had the widest adaptability and stable yield across the environment compared to other genotypes which have long vector. Although, their yields were below the average mean. On the other hand, genotypes G5 (Binadhan-17), G10 (BR11), G12 (BR23) and G23 (BRRI dhan46) had above average yield with short vector. Susanto et al., (2015) and Akmal et al., (2014) reported that genotype with the highest yield average was not necessarily be the most stable and vice versa.

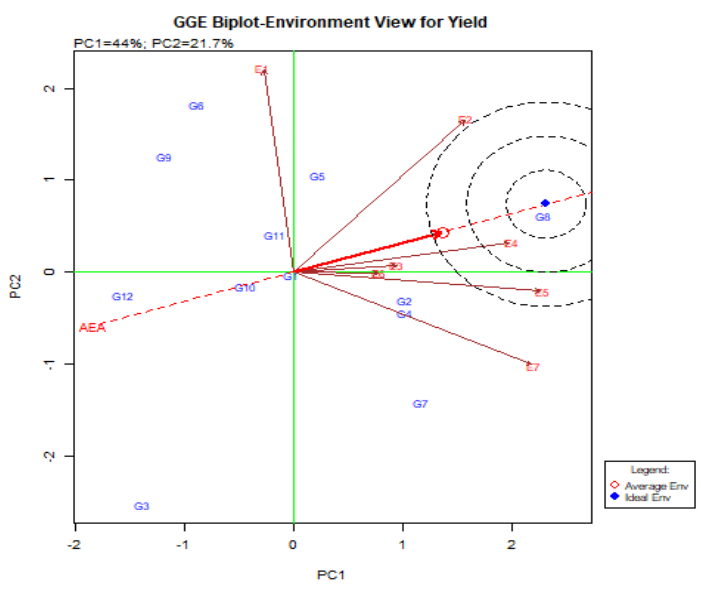

(b) Hybrid

Fig. 2. Identification of ideal environments based on the average environment axis (AEA), considering degree of angle of environmental vector evaluated across seven environments for grain yield. 
In the present study, it was observed that the highest yield was obtained in Khulna (4.69 tha$\left.{ }^{1}\right)$ followed by Barishal (4.53 tha $\left.{ }^{-1}\right)$ and Chattogram (4.21 tha- ${ }^{-1}$ (Table 4a). Positive environmental index in the location Chattogram (0.23), Khulna (0.71) and Barishal (0.55) indicated higher yield potential of the three locations. Khulna was the most favourable location followed by Chattogram and Barishal suggested almost all the genotypes had the potential to exploit these three locations.

In the hybrid varieties, G8 (BRRI hybrid dhan6) had highest yield based on the average from all the environments and it was visualized by its position in the concentric area of AEA line. G8 had the yield average of 5.20 tha $^{-1}$ (Table $4 \mathrm{~b}$ ) with vector deviation so close to the origin point of the vector, indicating the most stable genotype. G2 (BADC hybrid dhan-2), G4 (BADC hybrid dhan-6) and G5 (Bayer hybrid dhan-4) were also stable, indicated by their position almost near on the encircled area of AEA lines having very small vector deviation. Nevertheless, these genotypes had above average yield followed the others.

Table 4a. Location wise mean yield $\left(t h^{-1}\right)$, heritability in broad sense $\left(h^{2}\right)$ and environmental index of 36 inbred rainfed rice varieties in seven environments.

\begin{tabular}{|c|c|c|c|c|c|c|c|c|c|}
\hline Variety (Inbred) & Code & E1 & E2 & E3 & $\mathrm{E} 4$ & E5 & E6 & E7 & Mean \pm SE \\
\hline BR10 & G9 & $4.43 a$ & $5.37 \mathrm{a}$ & $5.30 \mathrm{a}$ & $4.67 \mathrm{a}$ & $4.47 \mathrm{a}$ & $3.20 \mathrm{~b}$ & $5.13 a$ & $4.65 \pm 0.17$ \\
\hline BR11 & G10 & $5.47 \mathrm{ab}$ & $4.87 \mathrm{~b}$ & $1.57 \mathrm{~d}$ & $6.13 a$ & $3.07 \mathrm{c}$ & $2.68 \mathrm{c}$ & $4.73 b$ & $4.07 \pm 0.35$ \\
\hline BR22 & G11 & $5.60 \mathrm{a}$ & $5.03 a$ & $2.17 \mathrm{~b}$ & $5.10 \mathrm{a}$ & $2.60 \mathrm{~b}$ & $2.91 b$ & $5.23 a$ & $4.09 \pm 0.31$ \\
\hline BR23 & $\mathrm{G} 22$ & $5.63 a$ & $4.23 b c$ & $4.00 \mathrm{bc}$ & $3.80 \mathrm{~cd}$ & $2.60 \mathrm{e}$ & $2.89 \mathrm{de}$ & $4.87 \mathrm{ab}$ & $4.00 \pm 0.23$ \\
\hline BR25 & G13 & $4.37 \mathrm{ab}$ & $3.53 b c$ & $1.63 \mathrm{~d}$ & $5.13 a$ & $2.67 \mathrm{c}$ & $2.79 \mathrm{c}$ & $3.23 \mathrm{c}$ & $3.34 \pm 0.24$ \\
\hline BRRI dhan30 & G14 & $5.23 a$ & $4.63 \mathrm{ab}$ & $3.83 b c$ & $5.03 a$ & $3.70 \mathrm{bc}$ & $3.12 \mathrm{c}$ & $4.33 \mathrm{ab}$ & $4.27 \pm 0.17$ \\
\hline BRRI dhan31 & G15 & $4.67 \mathrm{a}$ & $4.63 a$ & $5.43 a$ & $5.23 \mathrm{a}$ & $3.27 \mathrm{~b}$ & $3.06 \mathrm{~b}$ & $4.53 \mathrm{a}$ & $4.40 \pm 0.22$ \\
\hline BRRI dhan32 & G16 & $4.60 \mathrm{~b}$ & $5.07 \mathrm{ab}$ & $5.73 a$ & $5.20 \mathrm{ab}$ & $3.47 \mathrm{c}$ & $3.06 \mathrm{c}$ & $4.83 \mathrm{ab}$ & $4.57 \pm 0.22$ \\
\hline BRRI dhan33 & G17 & $4.07 \mathrm{~b}$ & $5.43 a$ & $2.93 c$ & $4.03 \mathrm{~b}$ & $3.00 \mathrm{c}$ & $2.75 c$ & $4.37 \mathrm{~b}$ & $3.80 \pm 0.21$ \\
\hline BRRI dhan34 & G18 & $4.03 a$ & $3.13 \mathrm{a}$ & $3.12 \mathrm{a}$ & $3.57 \mathrm{a}$ & $3.40 \mathrm{a}$ & $1.37 \mathrm{~b}$ & $3.23 \mathrm{a}$ & $3.12 \pm 0.18$ \\
\hline BRRI dhan37 & G19 & $3.13 b c$ & $5.30 \mathrm{a}$ & $2.37 \mathrm{~cd}$ & $3.67 \mathrm{~b}$ & $2.83 \mathrm{~b}-\mathrm{d}$ & $2.16 \mathrm{~d}$ & $3.03 b-d$ & $3.21 \pm 0.22$ \\
\hline BRRI dhan38 & G20 & $3.43 a b$ & $4.23 a$ & $1.90 \mathrm{~d}$ & $3.70 \mathrm{ab}$ & $2.97 \mathrm{bc}$ & $2.34 \mathrm{~cd}$ & $3.33 \mathrm{ab}$ & $3.13 \pm 0.17$ \\
\hline BRRI dhan39 & G21 & $4.07 \mathrm{ab}$ & $2.00 \mathrm{~d}$ & $4.70 \mathrm{a}$ & $4.50 \mathrm{ab}$ & $2.83 \mathrm{~cd}$ & $2.55 \mathrm{~d}$ & $3.63 b c$ & $3.47 \pm 0.22$ \\
\hline BRRI dhan 44 & G22 & $4.93 a$ & 5.13a & $1.43 \mathrm{c}$ & $5.53 a$ & $3.77 \mathrm{~b}$ & $2.85 b$ & $5.20 \mathrm{a}$ & $4.12 \pm 0.32$ \\
\hline BRRI dhan46 & $\mathrm{G} 23$ & $4.60 \mathrm{a}$ & $4.57 \mathrm{a}$ & $3.94 a b$ & $4.63 a$ & $2.57 \mathrm{c}$ & $3.04 b c$ & $4.23 \mathrm{a}$ & $3.94 \pm 0.18$ \\
\hline BRRI dhan 49 & G24 & $5.13 \mathrm{ab}$ & $4.37 \mathrm{bc}$ & $4.10 \mathrm{c}$ & $5.70 \mathrm{a}$ & $4.07 \mathrm{c}$ & $3.03 \mathrm{~d}$ & $4.83 a-c$ & $4.46 \pm 0.21$ \\
\hline BRRI dhan51 & G25 & $4.00 \mathrm{~b}$ & $5.77 \mathrm{a}$ & $2.23 \mathrm{~d}$ & $4.00 \mathrm{~b}$ & $2.70 \mathrm{~cd}$ & $2.77 \mathrm{~cd}$ & $3.53 b c$ & $3.57 \pm 0.25$ \\
\hline BRRI dhan52 & G26 & $5.63 a$ & $5.57 \mathrm{a}$ & $4.40 \mathrm{~b}$ & $5.10 \mathrm{ab}$ & $3.30 \mathrm{c}$ & $3.14 \mathrm{c}$ & $5.03 \mathrm{ab}$ & $4.60 \pm 0.23$ \\
\hline BRRI dhan56 & G27 & $3.93 \mathrm{ab}$ & $1.83 \mathrm{c}$ & $3.67 \mathrm{~b}$ & $4.77 \mathrm{a}$ & $4.17 \mathrm{ab}$ & $3.27 \mathrm{~b}$ & $3.53 b$ & $3.60 \pm 0.22$ \\
\hline BRRI dhan57 & G28 & $3.57 \mathrm{ab}$ & $2.60 \mathrm{c}$ & $3.03 b c$ & $4.10 \mathrm{a}$ & $4.27 \mathrm{a}$ & $3.05 b c$ & $3.03 b c$ & $3.38 \pm 0.15$ \\
\hline BRRI dhan62 & G29 & $4.03 a$ & $3.00 \mathrm{c}$ & $4.33 a$ & $4.00 \mathrm{ab}$ & $4.03 a$ & $2.74 \mathrm{bc}$ & $3.00 \mathrm{c}$ & $3.59 \pm 0.13$ \\
\hline BRRI dhan66 & G30 & $4.33 b c$ & $3.40 \mathrm{c}$ & $5.83 a$ & $4.00 \mathrm{c}$ & $5.07 \mathrm{ab}$ & $3.58 \mathrm{c}$ & $3.83 \mathrm{c}$ & $4.29 \pm 0.18$ \\
\hline BRRI dhan71 & G31 & $5.33 a$ & $3.90 \mathrm{bc}$ & $4.37 \mathrm{bc}$ & $4.33 b c$ & $5.43 a$ & $3.54 \mathrm{c}$ & $4.50 \mathrm{ab}$ & $4.49 \pm 0.17$ \\
\hline BRRI dhan72 & G32 & $5.20 \mathrm{a}$ & $5.13 a$ & $2.97 \mathrm{~b}$ & $5.50 \mathrm{a}$ & $5.07 \mathrm{a}$ & $3.35 b$ & $4.63 a$ & $4.55 \pm 0.22$ \\
\hline BRRI dhan73 & G33 & $3.57 \mathrm{~b}$ & $3.60 \mathrm{~b}$ & $5.13 a$ & $5.37 \mathrm{a}$ & $5.10 \mathrm{a}$ & $3.13 b$ & $3.53 b$ & $4.20 \pm 0.25$ \\
\hline
\end{tabular}

66 Debsharma et al. 
Table 4a. Continued.

\begin{tabular}{|c|c|c|c|c|c|c|c|c|c|}
\hline Variety (Inbred) & Code & E1 & E2 & E3 & E4 & E5 & E6 & E7 & Mean $\pm S E$ \\
\hline BRRI dhan75 & G34 & $4.13 b c$ & $3.80 \mathrm{c}$ & $4.97 \mathrm{ab}$ & $5.70 \mathrm{a}$ & $3.80 \mathrm{c}$ & $2.26 \mathrm{~d}$ & $3.70 \mathrm{c}$ & $4.05 \pm 0.24$ \\
\hline Binasail & G8 & $3.90 \mathrm{bc}$ & $2.90 \mathrm{~d}$ & $5.10 \mathrm{a}$ & $4.10 \mathrm{~b}$ & $3.70 \mathrm{~b}-\mathrm{d}$ & $2.89 \mathrm{~d}$ & $3.00 \mathrm{~cd}$ & $3.66 \pm 0.18$ \\
\hline Binadhan-4 & G6 & $5.23 \mathrm{ab}$ & $4.93 b$ & $1.33 \mathrm{~d}$ & $6.17 \mathrm{a}$ & $4.40 \mathrm{bc}$ & $3.57 \mathrm{c}$ & $4.40 \mathrm{bc}$ & $4.29 \pm 0.32$ \\
\hline Binadhan-7 & G7 & $5.67 a$ & $4.40 \mathrm{c}$ & $5.53 \mathrm{ab}$ & $4.10 \mathrm{c}$ & $4.67 \mathrm{bc}$ & $2.86 \mathrm{~d}$ & $4.03 c$ & $4.47 \pm 0.21$ \\
\hline Binadhan-11 & G1 & $5.87 \mathrm{a}$ & $3.90 b c$ & $3.97 \mathrm{bc}$ & $4.17 \mathrm{~b}$ & $5.50 \mathrm{a}$ & $3.14 \mathrm{c}$ & $3.93 b c$ & $4.35 \pm 0.21$ \\
\hline Binadhan-12 & $\mathrm{G} 2$ & $4.67 \mathrm{a}$ & $4.43 \mathrm{a}$ & $1.93 \mathrm{~d}$ & $4.17 \mathrm{ab}$ & $3.43 \mathrm{bc}$ & $2.92 \mathrm{C}$ & $4.23 \mathrm{ab}$ & $3.68 \pm 0.21$ \\
\hline Binadhan-15 & G3 & $3.97 b c$ & $5.23 \mathrm{a}$ & $1.67 \mathrm{e}$ & $4.67 \mathrm{ab}$ & $2.83 \mathrm{~d}$ & $3.27 \mathrm{~cd}$ & $4.10 b c$ & $3.68 \pm 0.25$ \\
\hline Binadhan-16 & G4 & $3.00 \mathrm{~d}$ & $3.27 \mathrm{~cd}$ & $4.97 \mathrm{ab}$ & $4.17 \mathrm{bc}$ & $5.50 \mathrm{a}$ & $2.47 \mathrm{~d}$ & $3.30 \mathrm{~cd}$ & $3.81 \pm 0.25$ \\
\hline Binadhan-17 & G5 & $4.60 \mathrm{~b}$ & $4.43 b c$ & $3.50 \mathrm{~cd}$ & $6.03 a$ & $4.77 \mathrm{~b}$ & $3.33 d$ & $4.30 \mathrm{bc}$ & $4.42 \pm 0.19$ \\
\hline BU dhan-1 & G35 & $4.40 \mathrm{a}$ & $4.30 \mathrm{ab}$ & $5.13 a$ & $4.67 \mathrm{a}$ & $5.10 \mathrm{a}$ & $2.94 \mathrm{c}$ & $3.43 b c$ & $4.28 \pm 0.18$ \\
\hline BU dhan-2 & G36 & $4.50 \mathrm{a}$ & $3.57 \mathrm{a}-\mathrm{c}$ & $2.80 \mathrm{c}$ & $4.00 \mathrm{ab}$ & $3.37 \mathrm{bc}$ & $3.54 \mathrm{bc}$ & $3.00 \mathrm{c}$ & $3.54 \pm 0.14$ \\
\hline \multicolumn{2}{|c|}{ Environmental mean } & 4.53 & 4.21 & 3.64 & 4.69 & 3.82 & 2.93 & 4.02 & 3.98 \\
\hline \multicolumn{2}{|c|}{ Environmental index } & 0.55 & 0.23 & -0.34 & 0.71 & -0.16 & -1.04 & 0.05 & 0.00 \\
\hline \multicolumn{2}{|c|}{ LSD at $5 \%$} & 0.73 & 0.44 & 1.22 & 0.52 & 0.25 & 0.29 & 0.22 & 0.87 \\
\hline \multicolumn{2}{|c|}{ Heritability } & 0.88 & 0.97 & 0.9 & 0.94 & 0.99 & 0.94 & 0.99 & 0.54 \\
\hline
\end{tabular}

Table $4 \mathrm{~b}$. Location wise mean yield (tha-1), heritability in broad sense $\left(h^{2}\right)$ and environmental index of 12 hybrid rainfed rice varieties in seven environments.

\begin{tabular}{|c|c|c|c|c|c|c|c|c|c|}
\hline Variety (Hybrid) & Code & E1 & E2 & E3 & E4 & E5 & E6 & E7 & Mean \pm SE \\
\hline BRRI hybrid dhan4 & G7 & $3.40 \mathrm{~cd}$ & $4.38 \mathrm{bc}$ & $4.13 \mathrm{~b}-\mathrm{d}$ & $6.17 \mathrm{a}$ & $4.93 \mathrm{~b}$ & $3.12 d$ & $4.50 \mathrm{bc}$ & $4.38 \pm 0.22$ \\
\hline BRRI hybrid dhan6 & G8 & $4.97 \mathrm{~b}$ & $5.07 \mathrm{~b}$ & $6.43 a$ & $6.43 a$ & $5.47 \mathrm{ab}$ & $3.38 \mathrm{c}$ & $4.67 \mathrm{~b}$ & $5.20 \pm .23$ \\
\hline Mukti-1(HB-12) & G11 & $5.37 \mathrm{a}$ & $3.93 b-d$ & $4.40 \mathrm{a}-\mathrm{c}$ & $4.97 \mathrm{ab}$ & $4.53 a-c$ & $2.95 \mathrm{~d}$ & $3.73 \mathrm{~cd}$ & $4.27 \pm 0.18$ \\
\hline Agro dhan-12 & G1 & $4.47 \mathrm{ab}$ & $4.63 a$ & $4.27 \mathrm{ab}$ & $4.67 \mathrm{a}$ & $4.30 \mathrm{ab}$ & $3.38 b$ & $3.83 \mathrm{ab}$ & $4.22 \pm 0.13$ \\
\hline Bayer hybrid dhan- 4 & G5 & $5.37 \mathrm{a}$ & $5.00 \mathrm{ab}$ & $3.67 \mathrm{~cd}$ & $5.47 \mathrm{a}$ & $3.90 \mathrm{~b}-\mathrm{d}$ & $3.03 \mathrm{~d}$ & $4.27 \mathrm{a}-\mathrm{c}$ & $4.39 \pm 0.20$ \\
\hline Bayer hybrid dhan-6 & G6 & $5.30 \mathrm{a}$ & $4.93 \mathrm{ab}$ & $4.00 \mathrm{bc}$ & $5.43 a$ & $3.20 \mathrm{~cd}$ & $3.48 \mathrm{~cd}$ & $2.43 \mathrm{~d}$ & $4.11 \pm 0.25$ \\
\hline Hera-10 & G9 & $5.27 \mathrm{a}$ & $4.03 \mathrm{~b}-\mathrm{d}$ & $4.70 \mathrm{a}-\mathrm{c}$ & $5.23 \mathrm{ab}$ & $3.63 \mathrm{~cd}$ & 2.98de & $2.07 \mathrm{e}$ & $3.99 \pm 0.25$ \\
\hline Hera-16 & G10 & $4.57 \mathrm{ab}$ & $4.14 \mathrm{bc}$ & $5.40 \mathrm{a}$ & $4.97 \mathrm{ab}$ & $3.23 \mathrm{~cd}$ & $2.75 d$ & $3.90 \mathrm{~b}-\mathrm{d}$ & $4.14 \pm 0.30$ \\
\hline Subrona-8 & G12 & $4.87 \mathrm{a}$ & $3.60 \mathrm{~b}$ & $3.93 \mathrm{ab}$ & $4.03 \mathrm{ab}$ & $3.07 \mathrm{~b}$ & $2.98 b$ & $3.53 b$ & $3.72 \pm 0.16$ \\
\hline BADC hybrid dhan-2 & $\mathrm{G} 2$ & $4.37 \mathrm{~b}$ & $4.50 \mathrm{~b}$ & $3.83 \mathrm{~b}$ & $6.13 a$ & $4.30 \mathrm{~b}$ & $4.81 \mathrm{~b}$ & $4.43 b$ & $4.63 \pm 0.16$ \\
\hline BADC hybrid dhan-6 & G4 & $4.23 \mathrm{~b}$ & $4.70 \mathrm{ab}$ & $4.43 \mathrm{ab}$ & $5.63 a$ & $4.60 \mathrm{ab}$ & $3.60 \mathrm{~b}$ & $4.60 \mathrm{ab}$ & $4.54 \pm 0.14$ \\
\hline BADC hybrid dhan-4 & G3 & $3.27 \mathrm{c}$ & $2.40 \mathrm{c}$ & $4.53 \mathrm{ab}$ & $4.67 \mathrm{a}$ & $3.43 \mathrm{bc}$ & $3.07 \mathrm{c}$ & $3.33 b c$ & $3.53 \pm 0.17$ \\
\hline \multicolumn{2}{|c|}{ Environmental mean } & 4.62 & 4.28 & 4.48 & 5.32 & 4.05 & 3.29 & 3.77 & 4.26 \\
\hline \multicolumn{2}{|c|}{ Environmental index } & 0.36 & 0.02 & 0.22 & 1.06 & -0.21 & -0.97 & -0.49 & 0.00 \\
\hline \multicolumn{2}{|l|}{ LSD at $5 \%$} & 0.81 & 0.84 & 1.48 & 0.79 & 0.31 & 0.34 & 0.33 & 0.66 \\
\hline \multicolumn{2}{|l|}{ Heritability } & 0.84 & 0.84 & 0.52 & 0.84 & 0.98 & 0.95 & 0.98 & 0.73 \\
\hline
\end{tabular}

Note: E1 $=$ Barishal, E2 $=$ Chattogram, E3 $=$ Dhaka, E4 $=$ Khulna, E5 $=$ Rajshahi, E6 $=$ Rangpur, E7 $=$ Sylhet, LSD $=$ Least significant difference, $\mathrm{SE}=$ Standard Error. 
The location Khulna (5.32 tha ${ }^{-1}$ ) had the highest yield followed by Barishal (4.62 tha-1) and Dhaka (4.48 tha-1) (Table 4b). Positive environmental index in the location Dhaka (0.22), Khulna (1.06) and Barishal (0.36) indicated higher yield potential of these locations. Khulna was the most favourable location followed by Dhaka and Barishal (Table 5) suggested almost all the genotypes had the potential to exploit these three locations. In addition, the presence of high heritability for grain yield in all the environments indicated reliability of the data. Besides this, high heritability is useful in the selection of the genotypes for high yield. This coincides with the report of Kaya et al., (2006) in wheat. Similarly Ceccarelli (1996) reported heritability is higher in high yielding environment than low yielding environment in barley (Hordeum vulgare L.) and Abdelmula et al., (2008) also found the similar report in faba bean (Vicia faba L.) (Table 4b).

\section{Identification of mega-environment based on which-won-where pattern}

Visualization of the which-won-where pattern of multi-location data is necessary for studying the possible existence of different mega environments in the target environment (Gauch and Zobel, 1997; Yan et al., 2000; Yan and Hunt, 2001). Mega-E is determined by the vertex genotype, i.e. the highest yield

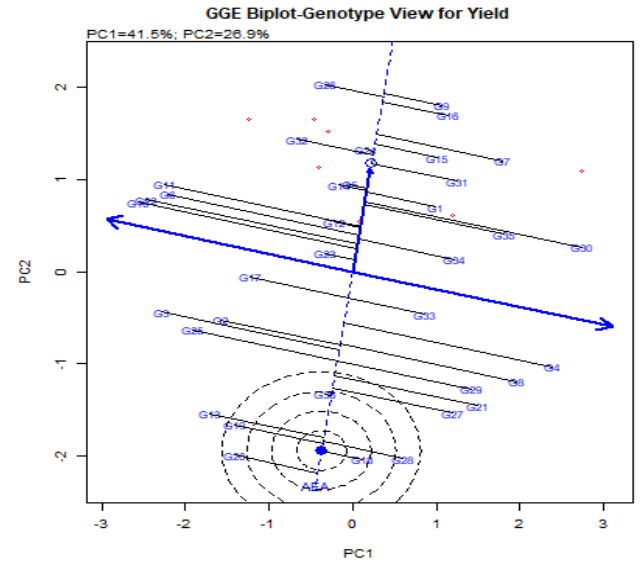

(a) Inbred genotypes in each quadran developed by GGE analysis visualization (Yan and Hunt, 2001). Position of the vertex genotypes were connected by connecting lines, i.e. a linear line started from the base of biplot that cross perpendicularly each connecting line and separated the biplots into some sectors. Sectors containing environments, i.e. sectors containing dots representing environments, called as Mega-E (Jambormias, 2011).

In the inbred study, biplot showed three sectors containing all the test environments and accordingly three mega-environments were identified (Fig. 4a): One megaenvironment had two locations, E3 (Dhaka) and E5 (Rajshahi); the second consisting of four locations, E1 (Barishal), E4 (Khulna), E6 (Rangpur) and E7 (Sylhet); the third had one location, E2 (Chattogram). G7 (Binadhan-7) and G30 (BRRI dhan66) were the winning varieties in the first mega-environment; G9 (BR10), G16 (BRRI dhan32) and G26 (BRRI dhan52) were the winner in the second; and G6 (Binadhan-4) and G11 (BR22) were the winning varieties in the third megaenvironment (Fig. 4a). G3 (Binadhan-15), G4 (Binadhan-16), G13 (BR25), G18 (BRRI dhan34), G19 (BRRI dhan37), G20 (BRRI dhan38) and G28 (BRRI dhan57) were the low yielder of inbred varieties evaluating the whole country.

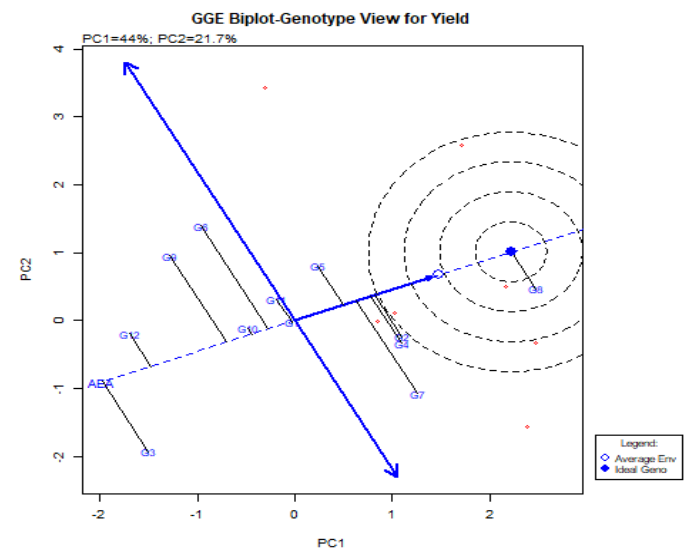

(b) Hybrid

Fig. 3. Average environment axis (AEA) view based on pooled mean performance and stability of 36 inbred and 12 hybrid rice genotypes during rainfed condition in 2018. 
Table 5. Summary of ideal environment and genotypes with stable and high mean yields in inbred and hybrid varieties.

\begin{tabular}{|c|c|c|c|c|c|}
\hline Category & $\begin{array}{l}\text { Ideal near ideal } \\
\text { genotype }\end{array}$ & Stable genotype & High mean & $\begin{array}{c}\text { Ideal near ideal } \\
\text { environment }\end{array}$ & $\begin{array}{c}\text { Most } \\
\text { discriminate } \\
\text { location }\end{array}$ \\
\hline Inbred & $\begin{array}{c}\text { G18 } \\
\text { (BRRI dhan34) }\end{array}$ & $\begin{array}{l}\text { G18 (BRRI dhan34) } \\
\text { G26 (BRRI dhan52) } \\
\text { G28 (BRRI dhan57) } \\
\text { G19 (BRRI dhan37) } \\
\text { G13 (BRRI dhan25) } \\
\text { G27 (BRRI dhan56) } \\
\text { G21 (BRRI dhan39) }\end{array}$ & $\begin{array}{c}\text { G9 } \\
\text { (BR10) } \\
\text { G26 } \\
\text { (BRRI dhan52) }\end{array}$ & $\begin{array}{c}\text { E6 } \\
\text { (Rangpur) }\end{array}$ & $\begin{array}{c}\text { E2 } \\
\text { (Chattogram) } \\
\text { E3 } \\
\text { (Dhaka) }\end{array}$ \\
\hline Hybrid & $\begin{array}{c}\text { G8 } \\
\text { (BRRI hybrid } \\
\text { dhan6) }\end{array}$ & $\begin{array}{l}\text { G8 (BRRI hybrid dhan6) } \\
\text { G2 (BADC hybrid dhan-2) } \\
\text { G4 (BADC hybrid dhan-6) } \\
\text { G5 (Bayer hybrid dhan-4) }\end{array}$ & $\begin{array}{c}\text { G8 } \\
\text { (BRRI hybrid } \\
\text { dhan6) } \\
\text { G2 } \\
\text { (BADC hybrid } \\
\text { dhan-2) }\end{array}$ & $\begin{array}{c}\text { E4 } \\
\text { (Khulna) }\end{array}$ & $\begin{array}{c}\text { E2 } \\
\text { (Chattogram) } \\
\text { E4 } \\
\text { (Khulna) } \\
\text { E5 } \\
\text { (Rajshahi) } \\
\text { E7 } \\
\text { (Sylhet) }\end{array}$ \\
\hline
\end{tabular}

The biplot was divided into two megaenvironments for hybrid varieties (Fig. 4b). The first mega-environment had six locations, E2 (Chattogram); E3 (Dhaka); E4 (Khulna); E5 (Rajshahi); E6 (Rangpur) and E7 (Sylhet) with G8 (BRRI hybrid dhan6) being the winning varieties. The second mega-environment consisted of one location, E1 (Barishal); and G6 (Bayer hybrid dhan-6) and G9 (Hera-10) as the winning varieties. G3 (BADC hybrid dhan-4); G7 (BRRI hybrid dhna4) and G12 (subrona-8) were the low yielder of hybrid varieties evaluating the tested locations (Fig. 4b). Also, those genotypes within the polygon (for example G2 and G4 for first megaenvironment) were less responsive to location than the winning genotypes (Karimizadeh et al., 2013).

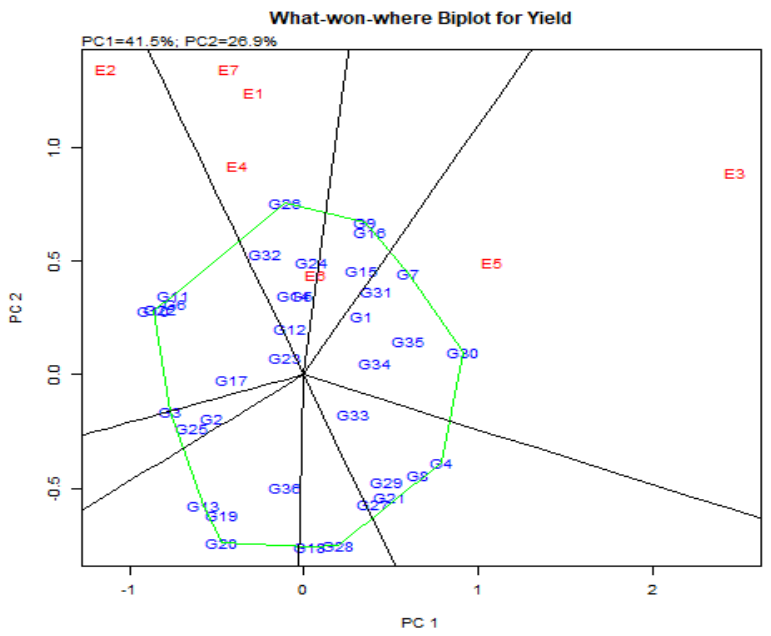

(a) Inbred

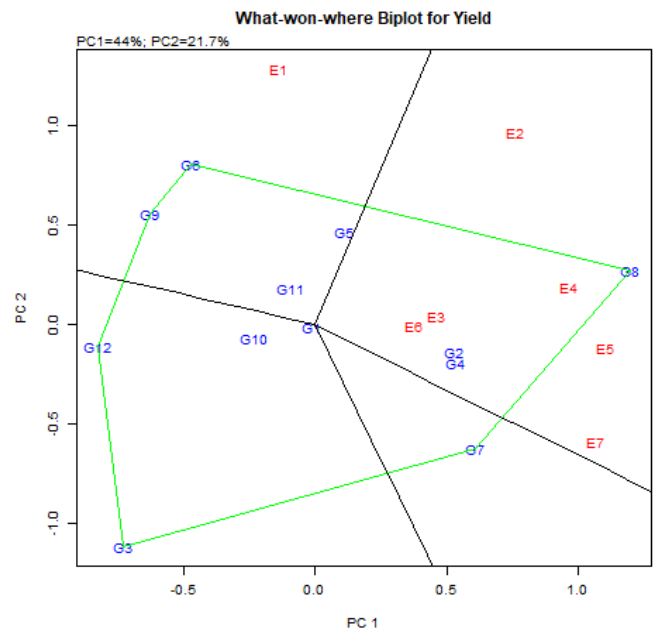

(b) Hybrid

Fig. 4. Identification of winning genotypes by GGE biplot and their related mega-environments during rainfed condition in 2018. 


\section{CONCLUSION}

The locations E2 (Chattogram); E3 (Dhaka) for inbred and E2 (Chattogram); E4 (Khulna); E5 (Rajshahi); E7 (Sylhet) for hybrid varieties were most discriminating and more informative locations. These respective locations could be used for decisions on genotypes to retain for further testing. Among the seven locations, ideal environment was found in E6 (Rangpur) for inbred and E4 (Khulna) for hybrid varieties. Genotypes G18 (BRRI dhan34); G26 (BRRI dhan52); G28 (BRRI dhan57); G19 (BRRI dhan37); G13 (BR25); G27 (BRRI dhan56); G21 (BRRI dhan39) for inbred and G2 (BADC hybrid dhan-2); G4 (BADC hybrid dhan-6); G5 (Bayer hybrid dhan-4) for hybrid were the most stable genotypes compared to all other genotypes. Among all the genotypes, G18 (BRRI dhan34) and G26 (BRRI hybrid dhan6) were the ideal genotype for both inbred and hybrid respectively. These genotypes could be used for commercial cultivation across different locations as well as used as potential breeding materials even for crossing program in the future inbred and hybrid rice research in Bangladesh.

\section{AUTHOR'S CONTRIBUTION}

SKD and KMI generated idea; PRR and RAB coordinated the experiment/research/project; SKD and RAB developed methodology; SKD and KMI provided scientific insights; PRR and RAB gathered data; SKD and KMI carried out analysis and synthesis; SKD and PRR did the writings of all versions of the manuscript; SKD, PRR and KMI performed critical review and editing; All authors read and approved the final manuscript.

\section{ACKNOWLEDGMENT}

Authors are grateful to the Seed Certification Agency (SCA), Ministry of Agriculture, Government of the People's Republic of Bangladesh for providing funds and other facilities to accomplish the research work.

\section{DECLARATION OF INTERESTS}

The authors declare that they have no known competing financial interests or personal relationships that could have appeared to influence the work reported in this paper.

\section{REFERENCES}

Abdelmula, A A, W Link, E Von Kittlitz and D Stelling. 2008. Heterosis and inheritance of drought tolerance in faba bean (Vicia faba L.). Plant Breeding, 118(6): 485-490. DOI: 10.1046/j.1439-0523.1999.00411.x

Aina, O O, A G O Dixon, I Paul, and E A Akinrinde. 2009. $\mathrm{G} \times \mathrm{E}$ interaction effects on yield and yield components of cassava (landraces and improved) genotypes in the savanna regions of Nigeria. African Journal of Biotechnology, 8(19): 4933-4945.

Akmal, C, Gunarsih and M Y Samaullah. 2014. Adaptation and stability of aromatic rice lines in North Sumatera (in Indonesian). Food Crop Research Journal, 33 (1): 9-16.

Akter, A, M J Hasan, M U Kulsum, M H Rahman, A K Paul, L F Lipi and S Akter. 2015. Genotype × environment interaction and yield stability analysis in hybrid rice (Oryza sativa L.) by AMMI biplot. Bangladesh Rice Journal, 19(2): 83-90.

Annicchiarico, P. 1997. Joint regression vs. AMMI analysis of genotype-environment interactions for cereals in Italy. Euphytica, 94(1): 53-62.

Ceccarelli, S. 1996. Adaptation to low / high input cultivation. Euphytica, 92(1): 203-214.

Comstock, R E and R H Moll. 1963. G x E interactions. Symposium on Statistical Genetics and Plant Breeding. National Academy Science National Research Council, Washington, D C, 164-196.

Debsharma, S K, P R Roy, R A Begum, P K Kundu, A K M Shalahuddin, K M Iftekharuddaula. 2020. GenotypeEnvironment Interaction and Stability for Yield of Inbred and Hybrid Rainfed Lowland Rice (Oryza sativa L.) Varieties in Bangladesh. North American Academic Research, 3(07): 223-233 DOI: 10.5281/zenodo.3960983

Dehghani, H, A Ebadi and A Yousefi. 2006. Biplot analysis of genotype by environment interaction for barley yield in Iran. Agonomy Journal, 98(2): 388-393. DOI: 10.2134/agronj2004.0310

Eberhart, S A and W A Russell. 1966. Stability parameters for comparing varieties. Crop Science, 6(1): 36-40

Farshadfar, E, M Rashidi, M M Jowkar and H Zali. 2013. GGE biplot analysis of genotype $\times$ environment interaction in chickpea genotypes. European Journal of Experimental Biology, 3 (1): 417-423. 
Fentie, M, A Assefa and K Belete. 2013. AMMI analysis of yield performance and stability of finger millet genotypes across different environments. World Journal of Agricultural Sciences, 9(3): 231-237.

Finlay K W and G N Wilkinson. 1963. The analysis of adaptation in a plant breeding programme. Australian Journal of Agricultural Research,14(6): 742-754.

Francis, T R and L W Kannenberg. 1978. Yield stability studies in short season maize. I. A descriptive method for grouping genotypes. Canadian Journal of Plant Science, 58(4): 1029-1034. DOI: 10.4141/cjps78-157

Gauch, H G and R W Zobel. 1988. Predictive and postdictive success of statistical analyses of yield trials. Theoretical and Applied Genetics, 76(1): 1-10.

Gauch, H G and R W Zobel. 1997. Identifying megaenvironments and targeting genotypes. Crop Science, 37(2), 311-326. DOI: 10.2135/cropsci1997.0011183X003700020002x

Iftekharuddaula, K M, K Akter, M S Hasan and M A Badshah. 2002. Genotype-environment interaction in irrigated rice in Bangladesh. Thai Journal of Agricultural Science, 35(3): 229-236.

Kaya, Y, M. Akcura and S Taner, 2006. GGE-Biplot analysis of multi-environment yield trials in bread wheat. Turkish Journal of Agriculture and Forestry, 30(5): 325-337.

Jambormias, E and J Riry. 2008. Application of GGE biplot for stability and adaptation evaluation of genotypes with multi- environment trials data. Jurnal Budidaya Pertanian, 4 (2): 84-93.

Jambormias, E. 2011. Describing of GGE-biplot graphics to evaluate genotypes performance and changes of environmental stress in small islands (in Indonesia). Proceedings of National Conference: Development of Small Islands (PERMAMA). University of Pattimura. Ambon. p. 299-310.

Karimizadeh, R, M Mohammadi, N Sabaghni, A A Mahmoodi, B Roustami, F Seyyedi and F Akbari. 2013. GGE Biplot analysis of yield stability in multienvironment trials of Lentil genotypes under rainfed condition. Notulae Scientia Biologicae, 5(2): 256-262. DOI: $10.15835 /$ nsb529067

Sharma, J R. 1994. Principles and practice of plant breeding. Tata McGraw-Hill Publishing Co. Ltd. New Delhi. 599

Samyuktha, S M, D Malarvizhi, A Karthikeyan, M Dhasarathan, A T Hemavathy, C Vanniarajan, V Sheela, S J Hepziba, M Pandiyan and N Senthil. 2020. Delineation of genotype $\times$ environment interaction for identification of stable genotypes to grain yield in mungbean. Front. Agron. 2: 577911. doi: 10.3389/fagro.
Shukla, G K. 1972. Some statistical aspects of partitioning genotype environment components of variability. Heredity, 29(2): 237-245.

Susanto, U, W R Rohaeni, S B Johnson and A Jamil. 2015. GGE biplot analysis for genotype-environment interaction on yield trait of high Fe content rice genotypes in Indonesian irrigated environments. Agrivita Volume, 37(3):265-275.

Pandey, B P, S K Srivastava and R S Lal. 1981. Genotype x Environment interaction in lentil. Lens, 8: 14-17.

Pinthus, J M. 1973. Estimate of genotype value: A proposed method. Euphytica, 22(1): 121-123

Wassmann, R, S V K Jagadish, S Heuer, A Ismail, E Redona, R Serraj, R K Singh, G Howell, H Pathak and K Sumfleth. 2009. Climate change affecting rice production: the physiological and agronomic basis for possible adaptation strategies. Donald L. Sparks (eds.). Advances in agronomy, Burlington: Academic Press, 101: 59-122.

Xu, F F, F F Tang, Y F Shao, Y L Chen, T Chuan and J S Bao. 2014. Genotype $\times$ environment interactions for agronomic traits of rice revealed by association mapping. Rice Science, 21(3): 133-141.

Yan, W and L A Hunt. 1998. Genotype by environment interaction and crop yields. Plant Breeding Reviews, 16: 135-178.

Yan, W. 1999. Methodology of cultivar evaluation based on yield trial data-with special reference to winter wheat in Ontario. PhD Thesis, University of Guleph, Guleph, Ontario, Canada.

Yan, W, L A Hunt, Q Sheng and Z Szlavnics. 2000. Cultivar evaluation and mega-environment investigation based on GGE biplot. Crop Science, 40(3): 597-605.

Yan, W and L A Hunt. 2001. Interpretation of genotype $\times$ environment interaction for winter wheat yield in Ontario. Crop Science, 41(1): 19-25.

Yan, W and I Rajcan. 2002. Biplot analysis of test sites and trait relations of soybean in Ontario. Crop science, 42(1): 11-20.

Yan, W and M S Kang. 2002. GGE Biplot Analysis: A graphical tool for breeders, geneticists and agronomists. CRC Press.

Yan, W and N A Tinker. 2006. Biplot analysis of multienvironment trial data: Principles and applications. Canadian Journal of Plant Science, 86(3): 623-645.

Yoshida, S, D A Forno, J H Cock and K A Gomez. 1976. Laboratory manual for physiological studies of rice. (3 $3^{\text {rd }}$ edn), International Rice Research Institute, Los Banos, Philippines. 